\title{
Unequal Exchange? Marx' Solution to the Value Problem on the World Market
}

\author{
Guenther Sandleben \\ Berlin School of Economics and Law, Berlin, Germany \\ Email: guenther.sandleben@t-online.de \\ Received 14 June 2016; accepted 16 July 2016; published 19 July 2016 \\ Copyright (C) 2016 by author and Scientific Research Publishing Inc. \\ This work is licensed under the Creative Commons Attribution International License (CC BY). \\ http://creativecommons.org/licenses/by/4.0/ \\ c) (i) Open Access
}

\section{Abstract}

By drawing on his critically developed labour theory of value, Marx was able to provide a satisfactory answer to the question of unequal exchange-that is, the question of how the law of value regulates exchange between two or more countries. Unlike the proponents of classical political economics, Marx drew an explicit distinction between labour, as expressed in the form of value, and the same labour, as expressed in the form of use value. This twofold character is the key to the correct analysis of magnitude of value and exchange relation. At the heart of Marx' solution to the value problem is the concept of "socially necessary labour time". This concept includes the average labour of a given country that is required to measure magnitude of value in relation to time. If the character of average labour differs from country to country, then the same quantity of labour time measures values that also differ from country to country. What is modified, then, is not the magnitude of value itself but labour time as a measure of value. Unlike in Ricardo's theory, in Marx's labour theory of value, the law of exchange also applies to international trade. As a general rule, what is exchanged are equivalents. In international trade, no country can acquire a value that is greater than the value it had before engaging in such trade. A transfer of value does not occur. Less developed countries can reproduce themselves as well without being competed out of the market by more developed nations. However, the exchange of equivalents involves unequal quantities of labour time, but this "unequal exchange" is determined by production. It is not a matter of exchange, and thus it is not a matter of exchange rates either.

\section{Keywords}

Unequal Exchange, Modification of the Law of Value, Socially Necessary Labour Time, Intensity of Labour, National Capital, Marx

\section{Introduction}

There is a consensus among proponents of the labour theory of value that the labour required for the production 
of commodities determines the commodities' value and the exchange relation between them. However, there is a disagreement over whether the law of value also applies to international trade, or whether it is modified or does not even apply to the world market at all. As early as 1817, the English economist David Ricardo, in his Portugal-England example, wrote about an exchange of English cloth whose production required the labour of 100 men for one year and Portuguese wine whose production required the labour of 80 men for one year. "Such an exchange", he noted, "could not take place between the individuals of the same country. The labour of 100 Englishmen cannot be given for that of 80 Englishmen" (Ricardo [1], p. 77). The consequence of this deviation is that the labour required to produce a commodity regulates exchange only on the domestic market but not on the world market.

Ricardo was unable to resolve this value problem, and yet his analysis still provides the foundations for the theory of unequal exchange to this day. Referring to the transfer of profits and to a secular deterioration of the terms of trade, the proponents of this theory conclude that the unequal exchange in international trade results in a transfer of national values from the developing to the industrialized countries. The theory of unequal exchange is also sometimes linked with Marx' labour theory of value (see [1] [2]). The purpose of the following analysis is to examine whether there is justification to do so.

\section{Using Marx's Term "Socially Necessary Labour Time" to Overcome the Shortcomings of Ricardo's Concept}

Ricardo's Portugal-England example implies that, regardless of the line of work, whether in the production of wine or the production of cloth, the labour of one Englishman always creates the same amount of value as the labour of another Englishman but not the same amount of value as the labour of a Portuguese. Ricardo thus implicitly assumed that labour was always the same throughout England and always the same throughout Portugal without asking himself what such equality of labour would actually entail. What he failed to realize is that the labour of 100 Englishmen can only be quantified if it is first reduced to equal human labour. Nowhere in his writings did he so much as raise the question of such equality of labour in contrast to labour represented in use value.

The discovery of this twofold character of labour embodied in commodities is, as Marx praised his own scientific achievement, "the pivot on which a clear comprehension of political economy turns" (Marx [2], p. 51). It is here that we also find the key to Marx' solution to the value problem on the world market.

The first aspect of the twofold character of labour that Marx discovered is that labour, as the creator of use value, has a qualitative side in that it is concrete useful labour; it "is determined by its aim, mode of operation, subject, means, and result" (Marx [2], p. 51). The second aspect is that labour that creates exchange value is reduced to labour without any additional quality; it is, as Marx calls this side of labour, "equal human labour", or "abstract human labour".

Ricardo treated the value-creating character of labour as something fixed and eternal, given by Nature, something no more remarkable than the ability to produce useful things, such as houses, clothes and so on. Following Adam Smith, he presented fishermen and hunters who lived in the early days of mankind as owners of commodities who exchanged fish and game in the proportion in which labour time is embodied in these exchange values. The classic proponents of labour theory of value regarded exchange not only as a natural inclination of man but also as the necessary condition for the social division of labour. They ignored the historically specific form of labour that gives labour products their specific value form and, ultimately, their specific money form in the first place. Because they regarded this social form of labour as an everlasting natural form, the theoretical difficulty presented itself of drawing a distinction between the social determination of labour as a creator of value and the concrete useful side of labour. They thus failed to see that the equality of all sorts of human labour is a condition for the equality of the value reality [Wertgegenständlichkeit] of the products of labour. As a result, they could not grasp the relationship between value and the development of money, nor could they understand the price form itself. The fact that the prices of production may systematically deviate from the corresponding magnitudes of value due to the law of the average rate of profit was either ignored (Adam Smith) or regarded as a mere exception to the rule (David Ricardo).

Naturally, the theoretical work on the magnitude of value suffered from shortcomings as well, and it was not until Marx presented his analysis of the relationship between abstract work and the determination of the magnitudes of value by socially necessary labour time that this problem was finally resolved. To measure the amount of labour, and with it the magnitude of value, in relation to time, all of the labour in question must be qualita- 
tively equal so that any differences become merely differences of magnitude. This involves a reduction to simple average social labour. Labour of a more complicated character is reduced to a multiple of such simple labour. Average labour means that the relatively longer time a clumsy or lazy labourer requires to produce the same commodity does not determine the magnitude of value of the commodity. What creates value is not this individual deviation but rather the "labour time socially necessary", that is, the time "required to produce an article under the normal conditions of production, and with the average degree of skill and intensity prevalent at the time” (Marx [2], p. 49).

In this passage Marx identified the two key factors that allow for the resolution to the value problem on the world market, namely "the normal conditions of production" and "the average degree of skill and intensity". It was not until this unit—average labour — was discovered that the magnitude of value could be measured in relation to labour time.

However, such a unit can only be regarded as given in an existing society; Marx makes a point of noting that average labour "varies in character in different countries and at different times" (Marx [2], p. 54).

This is precisely where the problem lies: if the character of average labour varies from country to country, then the amounts of labour and value measured in relation to the same quantity of labour time vary from country to country as well. Thus, in its application to national days of labour of equal length but different character the law of value is modified.

Marx characterized the two factors that play a major role in this modification in Chapter 22 (Chapter 20 of the German edition) of the second edition of Capital: Volume 1 with great analytical precision. For obvious reasons, Marx begins his analysis with a discussion of the degree of intensity.

\section{The Modification of the Law of Value as a Result of Different Degrees of Intensity}

For a better understanding of what follows, some preliminary remarks are in order about a concept discussed in Chapter 17 (Chapter 15 of the German edition), to which Marx refers in Chapter 22 (Chapter 20 of the German edition).

Increased intensity of labour means increased expenditure of labour in a given time. From this follows the first effect of intensity: a working day of more intense labour involves a larger quantum of labour being expended and thus a greater amount of value than does a working day of equal length but less intense labour.

The second effect can be derived in relation to the expression of value: provided the value of money remains unchanged, the greater amount of value necessarily expresses itself in a correspondingly greater amount of money.

The third effect is that, as a general rule, intensity influences not only the amount of value but also the amount of use value. Because a working day of more intense labour generates both more value and more products than does a working day of equal length but less intense labour, the value of the commodity in question remains unchanged. "Here we have an increase in the number of products, unaccompanied by a fall in their individual prices” (Marx [2], p. 524).

The purpose of these considerations is to analyze the following central passage from Chapter 22 (Chapter 20 in the German edition):

(1) In every country there is a certain average intensity of labour, below which the labour for the production of a commodity requires more than the socially necessary time, and therefore does not reckon as labour of normal quality. (2) Only a degree of intensity above the national average affects, in a given country, the measure of value by the mere duration of the working time. (3) This is not the case on the universal market, whose integral parts are the individual countries. (4) The average intensity of labour changes from country to country; here it is greater, there less. (5) These national averages form a scale, whose unit of measure is the average unit of universal labour. (6) The more intense national labour, therefore, as compared with the less intense, produces in the same time more value, which expresses itself in more money (Marx [2], pp. 558-559, Enumeration in brackets added).

Contrary to what some interpretations have suggested, in this passage Marx is not referring to "exchange rates", ${ }^{1}$ nor is he saying that commodities that enter international trade are accorded a different "international value". ${ }^{2}$ Such a modification would imply that a commodity has one of two values, depending on whether it is ${ }^{1}$ Proponents of this interpretation in Germany include Altvater, Neusüß, \& Blanke (see [3]) and Busch (see [4]).

${ }^{2}$ Cf. Kohlmey (see [5]). 
sold on the domestic market or on the international market.

In Sentence (1) of the passage quoted above Marx refers to "a certain average intensity of labour", which, he states, exists "[i]n every country". As we know, this "average intensity", which relates to a country, is implied in the concept of socially necessary labour time. There must be labour of average intensity and, related to it, "of normal quality" for the quantum of labour and thus the magnitude of value to be measurable in relation time.

Marx describes a case where labour "requires more than the socially necessary time". From the context it is clear that, because its intensity is below the national average intensity of the labour expended on the mass production of commodities, it "does not reckon as labour of normal quality". From this it follows that the larger quantity of labour time that a producer requires due to the lower intensity of labour cannot serve as the unit to measure the value. Rather, it is still the "socially necessary labour time"- that is, the time labour requires if it is expended under normal average social conditions - that must serve as the unit to measure value.

Another case is described in Sentence (2) above, which summarizes one of the main points discussed in Chapter 17 (Chapter 15 of the German edition). It states that the value product created by a working day of more intense labour "varies with the extent to which the intensity of labour deviates from its normal intensity in the society. A given working day, therefore, no longer creates a constant, but a variable value; in a day of 12 hours of ordinary intensity, the value created is, say 6 shillings, but with increased intensity, the value created may be 7, 8 or more shillings" (Marx [2], pp. 524-525).

A day of labour whose intensity deviates from the intensity that is normal in the society creates a greater value product - that is, a greater value - than does the socially necessary labour time of equal length. This is because labour of increased intensity has a greater influence on the value of production than does the labour to which the socially necessary work relates. In the latter case, average intensity serves as the unit of measurement; in the former case, it is increased intensity that does so. But, if labour of increased intensity creates a greater value product within the same amount of time than labour of normal quality, then, as Marx writes in Sentence (2), this higher degree of intensity affects "the measure of value by the mere duration of the working time".

This leads to the modification of the law of value even within a given country. However, what is modified is not the magnitude of value nor the exchange relation that is based on it; rather, what is modified is labour time in its function as a measure of value.

Sentence (3) then introduces the world market into the discussion, a market that is made up of a number of countries, each with their respective socially necessary conditions of production and intensity.

In Sentences (4) and (5), Marx emphasizes the difference of the respective national degrees of intensity. The hypothesis implied is that "average intensity" has no bearing on the world market. Rather, "the national averages form a scale" of degrees of intensity that vary from country to country.

In Sentence (6), Marx compares more intense national labour with labour of lower intensity. He makes two statements, which are easy to understand if we recall the first two effects of intensity from earlier. The first is that "more intense national labour" creates greater value in the same time than does "less intense" labour.

The second statement, that greater value "expresses itself in more money", already implies the second effect of intensity introduced above, namely that, provided the value of money remains unchanged, any value greater than another expresses itself in a correspondingly greater amount of money.

\section{Modifications of the Law of Value as a Result of Productivity Differentials}

Not only are there different national degrees of intensity on the world market; productivity varies from country to country as well. In Sentence (7) below, which immediately follows Sentence (6), Marx described the modification that results from such productivity differentials with utmost precision:

(7) But the law of value in its international application is yet more modified by this, that on the world market the more productive national labour reckons also as the more intense, so long as the more productive nation is not compelled by competition to lower the selling price of its commodities to the level of their value (Marx [2], p. 559).

Under what circumstances might a nation be compelled to do so?

Nowhere in the literature on unequal exchange and on the modification of the law of value on the world market is this question discussed in sufficient detail.

What is striking is that, according to Marx, only nations in which national labour is more productive are sometimes compelled to lower the selling price of their commodities; obviously this cannot happen in the case 
of more intense labour. Let us draw a comparison between intensity and productivity in order to understand what might compel a nation to lower selling prices. In this comparison the twofold character of labour will again play the decisive role. Productive power, which affects the efficacy of labour, is, as Marx emphasizes elsewhere, "an attribute of the concrete useful forms of labour" and, therefore, "can no longer have any bearing on that labour, so soon as we make abstraction from those concrete useful forms". As a general rule, "[h]owever then productive power may vary, the same labour, exercised during equal periods of time, always yields equal amounts of value. But it will yield, during equal periods of time, different quantities of values in use; more, if the productive power rise, fewer, if it fall” (Marx [2], p. 56). From this it follows that the value of a commodity should decrease if its production involves a greater degree of productivity. ${ }^{3}$ But this is not the case when intensity is increasing. From the discussion of the third effect of intensity we know that more intense labour does not lower the value of a commodity. Because the value remains constant in relation to a commodity, even a country that uses more intense labour is not necessarily compelled by competition to lower its selling price.

The omission, in his discussion of national differences in intensity, of any mention of the possibility that the selling price might have to be lowered was thus by no means an oversight on Marx's part.

If the nation with the more intense labour is not compelled to lower the prices of its commodities, then neither is the more productive national labour, but only as long as it "reckons also as the more intense".

The difficult question yet to be addressed is: When does the more productive labour count as the more intense labour, and when does it lose its effect, so that the selling prices start dropping to the lower level?

According to Marx' law of value, the magnitude of value of a commodity is measured not on the basis of individual labour time expended in a given case but on the basis of the socially necessary labour time expended by the mass of labour power. If a more productive power is adopted, then the more productive labour requires less time to produce a commodity than does the great mass of the other producers-it either produces the same value in less time, or it produces more value in the same time.

"The exceptionally productive labour", Marx can conclude, "operates as intensified labour; it creates in equal periods of time greater values than average social labour of the same kind" (Marx [2], p. 323).

Marx provides an example that shows how the coercive law of competition forces producers to lower prices and adopt the more productive power on a global scale until the reduced amount of time of the more productive labour is eventually established as the socially necessary labour time. At that point, the more productive labour no longer counts as more intense.

Sentence (7) above indicates that such a coercive law of competition that forces producers to lower prices can also apply on the world market: the more productive nation can be compelled by competition to lower the selling price of its commodities. If, for example, the productivity of labour increases in all branches of industry throughout the world at the same time and at the same rate, then the value product remains constant and the more productive labour produces more use values in the same time, with the result that the value of each commodity falls. In this case, the more productive labour does not count as more intense.

However, it is not always possible to generalize productive powers. Even on a domestic market there are some that only one capital can use. Marx' theory of economic rent assumes a productive power that can be monopolized. If, for example, a specific capital uses as a source of energy a waterfall to which other capitals do not have access, then the amount of socially necessary labour time required by those other capitals to produce a commodity is greater than the amount of individual labour time of the advantaged capital, which requires less than the average amount of labour because it has access to the waterfall. Thus its labour is relatively more productive. This, then, is a perfect example of a case where the more productive labour permanently counts as more intense.

On the world market the situation is as follows: the deciding factor that determines whether or not a more productive national labour counts as more intense labour for an extended period of time is whether the greater productive powers used by that national labour can be generalized to apply to other countries.

As the term "socially necessary labour time" itself makes clear, it is not possible to generalize certain productive powers in all cases. This term makes sense precisely because the socially normal conditions of production and intensity vary from country to country. If instead the generalization on the world market were as unabated as it is within a country, there would be no need to use the term "socially necessary labour time" in the first place. In that case, "the average unit of universal labour" that Marx uses in Sentence (4) to characterize different degrees of national intensity would suffice to measure the amount of labour, and with it the magnitude of value, in

\footnotetext{
3"The value of commodities is in inverse ratio to the productiveness of labour” (Marx [2], p. 324).
} 
relation to time. However, the fact that there is such a scale means that different national conditions of production exist alongside one another. If these conditions were homogenized throughout the world, there would be no modification problem on the world market. In such a case, "the individual countries" would no longer be "integral parts" of the world market (Sentence (3)); rather, the world market would merely be the sum of all the individual capitals, and the world market would be replaced by a world economy, as the Russian Marxist Nikolai Bukharin assumed almost a hundred years ago.

But if Marx intended for his concept of "socially necessary labour time" to apply not to global intensity and productivity but to the intensity and productivity of a given country, then that means that he assumes the existence of a total social capital [gesellschaftliches Gesamtkapital] whose characteristics are not discussed in greater detail until later in Capital, namely in Volumes II and III. His finding is that a country's total social capital—or "national capital", as Marx also calls it—has a quality of its own. It differs not only from the individual capitals of which it consists but also from the total social capitals of other countries, and varies by various factors including national intensity and productivity of labour, national wage level, rate of surplus value and equalization of profit rates "in the given nation" (Marx [6], p. 194). Such a total social capital has specific natural properties and involves social productive powers that are characterized by the variety of interlocked branches of production involved, by community institutions and by the size, density and skill level of the population. They are the shared monopoly of the individual capitals that operate as components of this total social capital. Such productive powers can only gradually be generalized to apply to other total social capitals, if at all. ${ }^{4}$ During this time the more productive national labour acts as more intense labour and modifies labour time as a measure of value.

\section{Unequal Exchange in International Trade?}

Ricardo did not understand the twofold character of labour. He did not investigate into the unit of measurement required to measure labour expended. He did not have at his disposal, the concept of "socially necessary labour time”, which was only developed later by Marx.

Without this concept, he could only consider value as an "amount of labour" whose size is determined by time or by the number of producers. To him, the labour of 100 Englishmen was an unmediated value, as was the labour product of 80 Portuguese. Equal exchange seemed impossible to achieve. For this reason, he concluded that "[t]he same rule which regulates the relative value of commodities in one country, does not regulate the relative value of the commodities exchanged between two or more countries” (Ricardo [1], p. 75).

The solution to the value problem is that Marx determines the value and the magnitude of value with precision: neither magnitude of value nor the exchange relation based on them is modified; the only thing that is modified is the measure of value based on the duration of working time alone.

Applied to Ricardo's Portugal-England example, Marx's finding is that the 100 Englishmen produce the same value as the 80 Portuguese because the intensity and productivity of the latter's labour (to the extent that it counts as more intense) is correspondingly greater. As a general rule, what is exchanged are equivalents. A transfer of value, such as from a less developed to a more highly developed country, does not occur. For this reason, a theory of the unequal exchange of values cannot base itself on Marx's ideas.

However, the equal values are the result of different quantities of labour time, which depend on national degree of intensity. But this "unequal exchange"-if indeed this is what one can call it with reference to labour time-is not a matter of exchange; it is a matter of production. It is the consequence of the fact that the stage of development of the capitalist mode of production varies from country to country.

Even if a less developed nation has to work longer than a more highly developed nation to export a commodity of the same value, it is not competed out of the market by it. The law of value provides the basis for the co-existence of a large number of national capitals that are in different stages of development.

That the exchange relations may be modified by economic-policy measures that reflect the asymmetry of power between countries is a question that falls outside the scope of this purely economic study because the

\footnotetext{
${ }^{4}$ For a detailed discussion (see Sandleben [7], pp. 78-90). Ricardo noted that capital finds it difficult to move on from one country to another; the economic reason for this difficulty is that equalization trends are blocked. Nikolai Bukharin [8], Henryk Grossmann [9], and other authors failed to appreciate this fact, and Arghiri Emmanuel [10], even explicitly rejected Ricardo's assumption of the relative immobility of capital. Because these authors regarded the world market as one single large total social capital and, at least in part, as a world economy, they drew wrong conclusions both about the trends of profit rate equalization and about the exchange relation. Marx, however, was unequivocal in considering the trends of profit rate equalization only in relation to the total social capital of a country. According to him, such equalization involves parts of the surplus value produced by production branches of a lower composition of capital being appropriated by capitals of a higher composition. In the case of a commodity produced under national average conditions (which includes capital composition), no value is transferred, not even within the country.
} 
point here is to develop the economic conditions for specific government action, not vice versa.

Nothing would be more absurd than to think that what Marx had in mind when he wrote about the modification of the law of value was a transformation of national values into international values. Values as different as these would be incompatible with the concept of value. When Marx writes that in "the trade between the markets of the world, the value of commodities is expressed so as to be universally recognized” (Marx [2], p. 153) he is referring to the money of the world, which expresses the values of the whole world of commodities.

The various different national uniforms of money have no bearing whatsoever on Marx' solution to the value problem. This is because magnitude of value is the condition for the expression of its value, which, however, is given a specific name of currency in each currency area.

As is generally known, Marx was never able to complete his studies, which would also have included analyses of international trade and of the world market (Volumes V and VI of the planned complete edition). But, as his brief yet extremely concise considerations in Volume I of Capital show, Marx had considered all elements of the law of value, including the effects of value on the world market.

\section{Acknowledgements}

Thanks to Jørgen Sandemose for constructive criticism.

\section{References}

[1] Ricardo, D. (2000) Principles of Political Economy and Taxation. 3rd Edition, In: McCulloch, J.R., Ed., The Works of David Ricardo, Esq., M. P.: With a Notice of the Life and Writings of the Author (Reprint), Lawbook Exchange, Union, NJ, 5-260.

[2] Karl Marx/Frederick Engels: Collected Works: Volume 35. Karl Marx: Capital, Vol. I. Lawrence \&Wishart, London.

[3] Altvater, E., Neusüß, C. and Blanke, B. (1971) Kapitalistischer Weltmarkt und Weltwährungskrise. Probleme des Klassenkampfs, 1, 5-116.

[4] Busch, K. (1974) Die multinationalen Konzerne: Zur Analyse der Weltmarktbewegung des Kapitals. Suhrkamp, Frankfurt am Main.

[5] Kohlmey, G. (1962) Karl Marx’ Theorie von den internationalen Werten, mit einigen Schlußfolgerungen für die Preisbildung im Außenhandel zwischen den sozialistischen Staaten. In: Jahrbuch des Instituts für Wirtschaftswissenschaften: Probleme der politischen Ökonomie, Vol. 5, The German Academy of Sciences at Berlin, East Berlin, 18-122.

[6] Karl Marx/Frederick Engels: Collected Works: Volume 37. Karl Marx: Capital, Vol. III. Lawrence \&Wishart, London.

[7] Sandleben, G. (2003) Nationalökonomie \& Staat: Zur Kritik der Theorie des Finanzkapitals. VSA, Hamburg, Germany.

[8] Bukharin, N. (1966) Imperialism and World Economy: With an Introduction by V. I. Lenin. H. Fertig, New York.

[9] Grossmann, H. (1967) Das Akkumulations- und Zusammenbruchsgesetz des kapitalistischen Systems: (Zugleich eine Krisentheorie) [Reprint]. Verlag Neue Kritik, Frankfurt am Main.

[10] Emmanuel, A. (1972). Unequal Exchange: A Study of the Imperialism of Trade. The Monthly Review Press, London, UK; New York. 


\section{Submit or recommend next manuscript to SCIRP and we will provide best service for you:}

Accepting pre-submission inquiries through Email, Facebook, LinkedIn, Twitter, etc.

A wide selection of journals (inclusive of 9 subjects, more than 200 journals)

Providing 24-hour high-quality service

User-friendly online submission system

Fair and swift peer-review system

Efficient typesetting and proofreading procedure

Display of the result of downloads and visits, as well as the number of cited articles

Maximum dissemination of your research work

Submit your manuscript at: http://papersubmission.scirp.org/ 